\title{
Effects of Fixed Capital Investments in current economic downturn
}

\author{
Marco Muscettola \\ Independent Researcher, Italy \\ marcomuscettola@hotmail.com
}

\begin{abstract}
The aim of this paper is to verify both the impact and influences when investing in fixed assets on probability of default. Using data from an extensive sample of Italian firms (6,000 Italian SMEs), we find that fixed assets are negatively related to efficiency and this fact leads to a greater instability with the consequence of a direct impact on the risk of insolvency. A portrait of firms in 2011, after the flash-over of the current economic downturn, subdividing them in firms that made fixed capital investments in 2008, three years before, and the others, which had no plan to increase tangible fixed assets. The results are consistent with the hypothesis that the solvency ought to decrease with rigidity of assets, especially in the area of commercial firms.
\end{abstract}

\section{Keywords}

Fixed assets, Firm structure, Default risk estimation

\section{Academic Discipline And Sub-Disciplines}

Financial modeling, Risk/Quantitative analysis, Financial Statement preparation, Model of rating, Corporate finance;

\section{SUBJECT CLASSIFICATION}

Corporate finance

\section{Council for Innovative Research}

Peer Review Research Publishing System

Journal: International Journal of Management \& Information Technology

Vol. 9, No. 3

editor@cirworld.com

www.cirworld.com, member.cirworld.com 


\section{INTRODUCTION}

Investment in fixed assets is essential dynamics for a firm. There are direct and indirect effects on a firm's profitability and risk, and consequently on its value. This capital is the investment in rigid assets and it is very decisive for a firm's survival. Firms can exploit their value by having an optimal level of working capital and of fixed assets. Large inventory and generous trade credit policy stimulate sales and reduce the risk of stock-outs. On the other side fixed assets are money locked up in inflexible capital. Long time period to convert the trade receivables or inventories can be expensive if a firm is not adequately capitalized. Similarly, a large portion of fixed assets can be costly for a firm since they must be supplied by a quite number of external sources. This is the situation which can lead to cash inflow difficulties for the firm itself.

The most evident consequence of an excessive rigidity of the assets is: to aggravate the burden of management also with higher costs of liquidation or costs of transfer of assets and indirect costs of failure. To these problems must be added the appreciation of the counterparty ratings, which associate higher probabilities of default to firms that are not flexible enough, with all the negative implications on their access to credit they may feature, or, almost, on the pricing of loans they were expecting.

Italy is a Country whose economy is pretty founded on the financial support of banks and, as easy to predict, the bank institutions are the real keystone on which firms hinge their cultures and average structures.

Italian banks, however, have always observed the old economical tradition, with both eyes wide open on the strong fundamentals and story of the relationship. In a firm, its knowledge as well as its whole experience are the essential elements to $x$-ray before every assessment of creditworthiness. To these variables there is the need to juxtapose the portion of equity on total capital of firm and the ability to provide adequate guarantees, both personal and material. This is the way to glimpse an easier chance to access to finance of firms with higher fixed assets that, accordingly, may even supply an adequate collateral in addition to the solidity idea.

Another indisputable point to highlight on the population taken in account of the present fieldwork, is the relationship between Italian people and the realty. Unlike many other people indeed, the Italianman has got his own opinion about the possession of the real estate, a desire that goes over the utility of the asset. People consider a house the goal of their entire lifetime at work, it means security and is synonym of apodictically safe investment. Many businessmen, therefore, are willing to sacrifice much more than the reasonable to reach their goal, to buy a property or, for private citizens, to become owners of a house is one of the most important targets.

Those two factors, linked to each other, often determine wrong valuations and, so, generate some productive investments that go far beyond the suitability.

This paper presents and develops a model framework which allows to estimate the effects of fixed capital investments on profitable growth of firms, costs structure, onerousness of debts and risk of default. As a matter of fact, it is a portrait of firms in 2011, after the flash-over of the current economic downturn, subdividing them in firms that made fixed capital investments in 2008, three years before, and the others, which had no plan to increase tangible fixed assets. The results are consistent with the hypothesis that the solvency ought to decrease with rigidity of assets, especially in the area of commercial firms.

Firms included within the sample we adopted will be subdivided into 750 companies that have made investments, increasing the total tangible assets, of over 15\%; and 5,250 companies that, vice versa, underwent that percentage proportion when they increased their fixed assets. Both sub-samples will be analyzed by economic indicators, financial ratios, efficiency variables and solvency markers.

Since there were still a lack of studies, a complete research published with the same intents and purposes on Italian territory, this sample contains a quite extremely various collection of selected Italian SMEs. For calculating interrelation results and investment impacts, in this study, we use and develop the data before the crisis period (2008). Descriptive analysis, through the examination of 6,000 Italian SMEs, shows us the effectiveness of using composition of assets to reduce the overall risk of default. And these data are acceptable values during the crisis. According to our hypothesis, therefore, expansion in fixed assets as a result of higher investment implies an amplified vulnerability of companies. This is emphasized in a time of crisis like the present days.

The paper is organized as follow. The research issues and literature review will be covered in next session 2 . Then, descriptive analysis and conceptual definitions are introduced in session 3. Session 4 goes on describing the data in the cluster analysis. Session 5 presents empirical results and findings. Lastly, session 6 shows discussion and conclusion on results achieved.

\section{LIBRARY REVIEW}

The liquidable of assets ultimately affects both the capital structure and the structure of production and trade costs. In this sense (Pulvino, 1998), literature confirms that economic and financial condition of firms is cause, and at the same time consequence, of rigidity of assets. Schlingemann et al (2002) support the hypothesis that the cost of sales and the bankruptcy cost get lower in sectors with more liquid assets. On the other side, thus, companies with more rigid assets will suffer a heavier onerousness of sales and a higher risk of default.

By an outright test, Alderson and Betker (1995) take in account liquidation costs of assets and the capital structure of an amount of 88 firms got insolvent, indicating that manufacturing firms with major additional costs of production and 
sale were the most prone to arrange their own capital structure with a lower short-term debt or, anyway, with a larger financial independence in order to counterbalance major bankruptcy costs. Similarly, during the economic downturn phases, Kim (1998) notices how firms with assets more inflexible avoid increasing their debt exposure unlike companies with more liquid assets. Everything above supports the thesis that a positive relationship stands between liquidity of assets and borrowing capacity of firms that inescapably passes through the riskiness of the same firms.

Along the years there has been a great debate on the existence, more or less, of a link, and of what kind, between the elasticity of assets and the composition of financing sources. By the way, a particular mention must go to the essential works carried out by Williamson (1988), Shleifer e Vishny (1992), Morellec (2001), and Myers and Rajan (1998). Selfcontradictory, therefore, is the relationship between the cost of new debt and the rigidity of the financial assets. Inelastic assets, long-established, and easily quantifiable form a valid guarantee for the lender. That way not highly liquid assets lead to positive impacts on access to bank credit, for example, as the same fixed assets constitute a possible collateral for new loans. On the other hand, as we have perceived, a higher stiffness of the assets also leads the firm to be more unstable and riskier. About this matter the empirical evidence is more oriented to affirm that there is a negative relationship (minor fixed assets - major debt) motivated primarily by the desire of the firm to offset the negative effects of an amplified rigidity of assets with lower payables.

Ultimately, there is who, like Muscettola (2014a), conceives that the relation between the total fixed assets and the level of debt is curvilinear.

Another fundamental point to comprehend the possible bonds is to ascertain the effective cost of the process of conversion into cash of assets. Some studies highlighted that distressed companies sell, of course, their products at the most discounted prices and most of firms would rather work with a greater prudential liquidity than necessary to get productive. Now it is easy to realize why distressed companies do not invest in fixed assets.

Shleifer and Vishny (1991), after having confirmed the theory, that the link between asset's liquidity and debt depends also on the level of rigidity as it relates to the firms, even assess that the significance of the connection between the two entities depends, first of all, on the probability of default for the firm itself. Whenever a firm has barely got probabilities to enter into a state of crisis, therefore, the variation in liquidity of total assets is not a direct or significant cause of deleveraging.

Few years later, Valery Sibilkov (2004) proved, using a sample based on American firms, to test in a scientific way the reaction in terms of level of indebtedness to the variations of fixed assets inside businesses. By a time frame of twoyear evolution, he has statistically classified the effects on the leverage of the liquidity ratios as positive and significative. This thesis, broadly shared by the most of American economists, also affirms that the structure of assets of company causes capital structure and not the opposite fact, not the consequence and, as a conclusion (Muscettola, 2013), every change set on fixed assets takes detriment to the optimal leverage.

The theories mentioned to this point could have a further positive contribution if, empirically analyzing our sample, there could be a demonstration that firms which invested in fixed assets, before the economic crisis of 2008, found higher insolvency risks than firms which did not care to make their assets more rigid than in the past.

Similarly, it has to be verified what impact on the profitability could divert fixed capital investments and whether it can, or not, alert us if a generalized decline in productivity due to the economic crisis may occur in the meantime.

\section{CONCEPTUAL DEFINITIONS AND DATASET}

In order to better study the effects of fixed capital investments, the sub-samples of firms will be subdivided in three clusters, equally distributed in account of their sectors (2,000 manufacturing firms, 2,000 commercial firms, 2,000 service firms). Inside each of the three groups there will be 250 firms which invested in fixed assets, and 1,750 which did not the same during 2008. After distinguishing firms by type of business conducted, it is going to ease the reading of all the results of the analysis carried out. It features as "firms that have invested in fixed assets", those firms that during 2008 increased fixed assets (tangible fixed assets) of over 15\% than in 2007 . All of other firms, differently, will be defined "firms that have not invested in fixed assets".

In this study "fixed assets" are "tangible fixed assets" as FRS 15 (Accounting standards Board - Financial Reporting Standard) sets out the principles of accounting for tangible fixed assets ${ }^{1}$. Fixed assets are sometimes collectively referred to as property, plant and equipment. This group includes as an asset land, buildings, tools, machinery, furniture, IT equipment, et cetera. They are written, in a balance sheet, off against profits over their anticipated life by charging depreciation expenses. Investments in tangible fixed assets, investments in securities, in sinking funds, longterm investments, common stock, long-term notes, insurance, financial assets, receivables, nonphysical assets, and all examples of intangible assets will not be taken in account of this essay.

It has been carried out a deep sweeping of the dataset cutting off from the sample control any firm that presented irrational data or strong fluctuations, through the years of survey, in sales, in total assets, in total liabilities or in net returns. Nevertheless we also prevented the inclusion of firms with less than 8 years of business, of firms that operate

\footnotetext{
${ }^{1}$ "Assets that have physical substance and are held for use in the production or supply of goods or services, for rental to others, or for administrative purposes on a continuing basis in the reporting entity's activities". A long-term tangible section of property that a firm doesn't expected to be consumed or converted into cash. These are purchased for continued and long-term use in earning profit in a 
as a dependent entity or a trading subsidiary of the parent companies and of firms that have a controlling stake in one or more companies. The analysis doesn't cover all the firms which got insolvent in 2008, in 2009 and in 2010 and aren't included property companies or financial companies. In the end, the final data set included 6,000 Italian SMEs.

Table 1: Characteristics of the sample used in the research

\begin{tabular}{|ccc|c|c|}
\hline & & Total firms & Defaults & \% defaults \\
\hline \multirow{2}{*}{$\begin{array}{c}\text { Commercial } \\
\text { firms }\end{array}$} & Firms that have invested in fixed assets & 250 & 33 & 13.20 \\
& Firms that have not invested in fixed assets & 1,750 & 67 & 3.83 \\
\hline \multirow{2}{*}{$\begin{array}{c}\text { Manufacturing } \\
\text { firms }\end{array}$} & Firms that have invested in fixed assets & 250 & 100 & 5.00 \\
\hline \multirow{2}{*}{$\begin{array}{c}\text { Service firms that have not invested in fixed assets } \\
\text { Firms }\end{array}$} & Firms that have not invested in fixed assets & 1,750 & 87 & 5.20 \\
& & 2,000 & 100 & 5.97 \\
\hline
\end{tabular}

For what it may concern insolvent firms, it has been adopted the objective definition of Basel II. A firm has to be considered as "default-grade" during year 2011 if in that year the Central Credit Register reports the existence of credit overdue for more than three months ${ }^{2}$.

Besides the aforementioned variable featuring as tangible fixed assets on total assets written both as ratio and as variation related to the previous year (year to year variation), the other explanatory variables are going to be described on table 2. The same table portrays all the definitions for the indices studied (variables) as well as any explanation about their calculation (ratio).

Table 2: Explanatory variables

\begin{tabular}{cc} 
VARIABLES & RATIO \\
\hline Size & Total Sales \\
Financial debts & Financial debts / Total Assets \\
Financial equilibrium & Current ratio \\
Return on debts & Interest expense / Total debts \\
Profitability & Operating profit / Sales \\
Efficiency & Ebitda / Interest expense \\
Return on investment & Operating profit / Total investment \\
Financial leverage & Financial debts / Equity
\end{tabular}

Prior to applying the empirical analysis we go on emphasizing the featured differences during 2008 regarding the composition of assets. The analysis of the following graph is absolute necessary to find out how firms may have a different capital structure and a different liquidity of assets especially related to the types of business activities (Muscettola \& Pietrovito, 2013b). Just for that reason, not to condition the achievements, it has been decided to keep divided all the samples, and by sectors, too (Muscettola \& Gallo, 2010).

For that purpose, it must be said that the levels of total assets and fixed assets inside of any balance of the analyzed firms, change according to the sector to which each of them belongs. Commercial firms inevitably have lower total assets (average EUR 9.07 million) than manufacturing firms that, instead, have total assets exceeding EUR 13.5 million.

\footnotetext{
${ }^{2}$ Those firms that have been reported by the Central Credit Register of the Bank of Italy as distressed and past-due, the firms that have started bankruptcy proceedings, and the companies that have a serious deleterious act report will be defined "insolvent firms".
} 


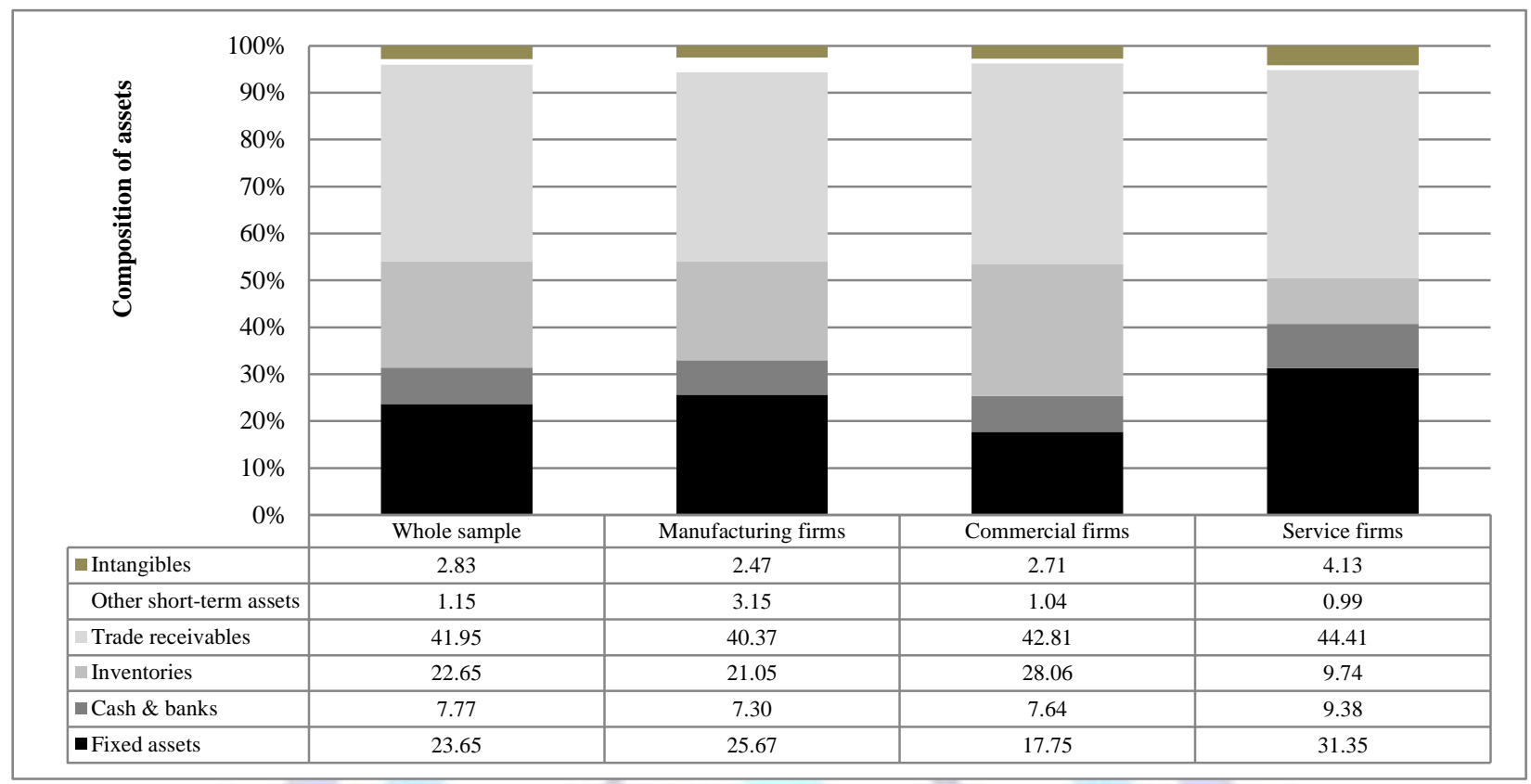

Figure 1: Composition of assets

Not only amplitudes vary, as described on figure 1, but even the percent composition of assets. Commercial firms have a relative majority of inventories and lower fixed assets, while service firms have got a shortage of inventories and more fixed assets. Trade receivables remain quite stable even shifting sector, exceeding $40 \%$ of total assets at any time.

\section{DESCRIPTIVE ANALYSIS}

Before going into detail with the study of averages of the sub-samples of the analyzed firms, it is almost clear watching the illustration of the dataset used into the study - that there is a majority of insolvencies among those firms which made investments in tangible fixed assets three years before. Looking back at table 1, indeed, the most of default cases really occurs among firms with increased fixed assets in commercial firms sector (13.20\%) and in service firms sector (10.4\%). There is no change, instead, for the default frequency of the sub-sample of manufacturing firms.

Starting from those first data, it is already possible to ponder on the effects of fixed capital investments in the current economic downturn, especially if they are conspicuous and related to sectors to which it is not essential, for the business activity, to adopt a quite large infrastructure or substantial machinery. Differently goes the industry sector, where tools, machinery and equipment often are synonym of increased corporate profitability.

The subsequent descriptive analysis is based on the following table. This time the analysis has been carried out on the averages of the eight explanatory variables displayed in the previous paragraph as they may vary according to the reference year, the sector, and, nevertheless, the investment grade in tangible fixed assets.

About the total sales (size), regardless of investments in fixed assets, significant details do not stand out. In this regard it is clear that sales revenues between 2008 and 2011 have been on the wane, especially due to the aftermath that had followed the economic crisis. However, the robust relationship between investment and production process or sales was not found.

Much more newsworthy, instead, the increase of financial indebtedness (financial debts) is in a pretty manifest wise for those firms which invested in tangible fixed assets (in the order of about $+3.00 \%$ ), while the same does not apply for other firms, as it stands stable or slightly goes down through the years. The economic crisis earlier produced a partial reduction of global consumption as well as minor productive investments to firms. Reducing financial requirements, therefore, causes the firms' habit to elicit lower borrowings, related to total assets.

Even concerning the financial stability (financial equilibrium), it is to attribute to the economic crisis all the effects of a total amelioration about the variable - current ratio. Nevertheless, with a slower inventory turnover due to minor sales as well as to harder credit collection, a criticism on an overall increase of the working capital factor goes without saying (Muscettola, 2014b). About firms without investments into tangible fixed assets, that increase stands much more self-evident.

The first prominent changes to indicate are about the variations of the averages of index ROD (return on debt) between 2008 and 2011. This time the difference is noticeable. Companies that in 2008 heightened over 15\% their 
tangible fixed assets, ineluctably enjoy a ROD increased in 2011. To firms that instead did not invest in fixed assets on such a scale, then, a lower ROD occurs in 2011.

Table 3: Means of explanatory variables

\begin{tabular}{|c|c|c|c|c|c|c|c|c|c|}
\hline Means & $\begin{array}{l}\text { ه } \\
\stackrel{2}{2}\end{array}$ & 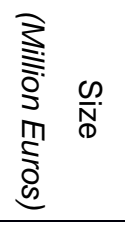 & 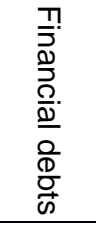 & 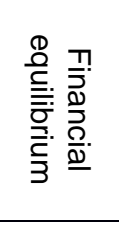 & 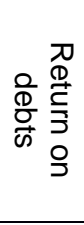 & 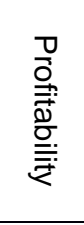 & 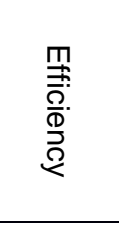 & 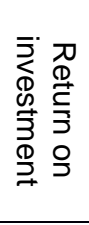 & 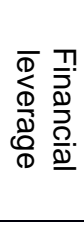 \\
\hline \multicolumn{10}{|c|}{ Commercial Firms } \\
\hline \multirow{2}{*}{$\begin{array}{l}\text { Firms that have invested in } \\
\text { fixed assets }\end{array}$} & 2008 & 13,923 & 19,99 & 141,47 & 1,97 & 3,29 & 250,84 & 7,65 & 1,68 \\
\hline & 2011 & 13,537 & 23,72 & 148,10 & 2,11 & 2,08 & 216,30 & 4,90 & 2,05 \\
\hline \multirow{2}{*}{$\begin{array}{l}\text { Firms that have not invested } \\
\text { in fixed assets }\end{array}$} & 2008 & 13,769 & 23,86 & 131,48 & 2,25 & 3,29 & 190,39 & 6,82 & 2,31 \\
\hline & 2011 & 13,521 & 24,27 & 145,05 & 2,14 & 2,01 & 208,20 & 4,38 & 1,94 \\
\hline \multicolumn{10}{|c|}{ Manufacturing Firms } \\
\hline \multirow{2}{*}{$\begin{array}{l}\text { Firms that have invested in } \\
\text { fixed assets }\end{array}$} & 2008 & 13,943 & 22,99 & 158,84 & 2,00 & 5,44 & 310,47 & 9,17 & 1,85 \\
\hline & 2011 & 12,726 & 25,99 & 161,97 & 2,11 & 1,39 & 239,82 & 2,94 & 1,48 \\
\hline \multirow{2}{*}{$\begin{array}{l}\text { Firms that have not invested } \\
\text { in fixed assets }\end{array}$} & 2008 & 14,026 & 24,79 & 146,48 & 2,23 & 4,80 & 173,14 & 7,19 & 1,93 \\
\hline & 2011 & 12,979 & 24,55 & 163,76 & 2,09 & 2,55 & 235,11 & 4,21 & 1,48 \\
\hline \multicolumn{10}{|c|}{ Service Firms } \\
\hline \multirow{2}{*}{$\begin{array}{l}\text { Firms that have invested in } \\
\text { fixed assets }\end{array}$} & 2008 & 12,233 & 13,91 & 146,84 & 1,55 & 4,87 & 469,26 & 9,32 & 1,06 \\
\hline & 2011 & 12,922 & 17,20 & 137,93 & 1,53 & 0,95 & 418,11 & 3,46 & 1,93 \\
\hline \multirow{2}{*}{$\begin{array}{l}\text { Firms that have not invested } \\
\text { in fixed assets }\end{array}$} & 2008 & 11,975 & 19,99 & 131,79 & 1,98 & 5,10 & 358,90 & 7,46 & 1,86 \\
\hline & 2011 & 12,871 & 19,54 & 139,85 & 1,85 & 3,32 & 489,41 & 4,80 & 1,48 \\
\hline
\end{tabular}

Regarding the corporate profitability, it is remarkable a lower ROS (return on sales) in 2011; that anyhow applies to all, whether types or sector of businesses we talk of. The reasons are a matter of the current economic downturn. Going in the detail, it is visible a worsening of the profitability much stronger for firms that invested in tangible fixed assets. In this regard, it is to remark that the operating profit has been calculated charging to the Ebitda also depreciation and amortization which, due to an investment in equipment, indeed, must be considered of course more onerous to firms that increased their own fixed assets.

Just like the ROD, the index describing the efficiency (Ebitda on interest expense) comes out clearly worsened to firms which invested in tangible fixed assets but also improved to all the others. To this purpose, in 2011, the averages of that index, both for commercial firms and manufacturing firms, converge towards similar values. The concept still remains: who invested in fixed assets in 2008, already started from a better point in terms of efficiency and performance, giving the sensation that a firm which built up its tangible fixed assets, well, it might do it encouraged by the strong support brought to it by the borrowed capital.

Looking at the other efficiency ratio, the ROI (return on investment), that slump had been standardized by sector and type of businesses. Going better in the merits, in firms that invested in fixed assets that slump turned sometimes into a kind of breakdown in the end.

Unlike other variables, the financial leverage portrays an averages trend which is not so eligible for all each of the cases studied. Commercial firms displayed a response more similar to that already met for the ROD and also for the financial indebtedness and, therefore, there is an upgrade of the financial position of firms that invested in fixed assets three years before; conversely, there is a decrease about the financial leverage for the other firms. Also for service firms, but much less clearly than all of that has been explored so far, for the ROD and the financial indebtedness, things go the same way as for the aforementioned cases. The only exception stands in the sector of manufacturing firms, that endures an identical reduction of debts on net worth, without taking in account those investments put in tangible fixed assets three years before.

In the end, Table 3 inevitably assesses that, in spite of the global economic crisis, it is easy to find out several structure differences among the sample of firms that invested in tangible fixed assets, rather than other firms.

The perception takes hold, that those firms definitively lost the greater solvency which characterized them three years before, worsening their own financial statements. 
So they got more vulnerable, conforming themselves to the standards of other firms.

\section{EMPIRICAL ANALYSIS}

After having built a new dataset containing the annual percentage changes of financial ratios between 2008 and 2007 , representing in the present study the explanatory variables for the sample, with the support of the logistic regression it is finally possible an audit upon the effects on the probability of default in 2011 after three years (Muscettola \& Naccarato, 2013). Besides the annual percentage changes of the eight explanatory variables illustrated in paragraph 3 , a mention goes to the index represented by tangible fixed assets on total assets, which underwent a particular variation.

The technique of logistic regression allows us to build three regression functions, one for each macro-sector, able of distinguishing solvency firms from insolvent firms. The logit regression with the backward selection is calculated by relying exclusively on the nine indicators calculated as specified in previous paragraph.

Stepwise regression with the backward elimination involves starting with the nine predictive variables, testing the deletion of each variable using a chosen model comparison criterion, deleting the variable that improves the model the most by being deleted, and repeating this procedure until no further improvement is possible.

Table 4: Stepwise logistic regression, with the backward elimination, calculated on commercial firms in the year 2008 and with, as a dependent variable, the firm's default after three years.

\begin{tabular}{|c|c|c|c|c|c|c|}
\hline & $\bar{\beta}$ & E.S. & Wald & Sig. & \multicolumn{2}{|c|}{$\operatorname{Exp}(\beta)$} \\
\hline \multirow{10}{*}{ Step 1} & Size & 0.006 & 0.004 & 2.303 & 0.129 & 1.006 \\
\hline & Fixed assets & 0.008 & 0.003 & 9.919 & 0.002 & 1.008 \\
\hline & Financial debts & 0.001 & 0.001 & 0.553 & 0.457 & 1.001 \\
\hline & Financial equilibrium & -0.011 & 0.007 & 2.673 & 0.102 & 0.989 \\
\hline & Return on debts & -0.001 & 0.001 & 0.507 & 0.476 & 0.999 \\
\hline & Profitability & 0.004 & 0.003 & 2.402 & 0.121 & 1.004 \\
\hline & Efficiency & -0.002 & 0.001 & 3.151 & 0.076 & 0.998 \\
\hline & Return on investment & -0.003 & 0.003 & 1.339 & 0.247 & 0.997 \\
\hline & Financial leverage & 0.001 & 0.001 & 0.785 & 0.376 & 1.001 \\
\hline & Constant & -3.742 & 0.128 & 857.868 & 0.000 & 0.024 \\
\hline \multirow{9}{*}{ Step 2} & Size & 0.006 & 0.004 & 2.449 & 0.118 & 1.007 \\
\hline & Fixed assets & 0.008 & 0.003 & 10.331 & 0.001 & 1.008 \\
\hline & Financial equilibrium & -0.011 & 0.007 & 2.780 & 0.095 & 0.989 \\
\hline & Return on debts & -0.001 & 0.001 & 0.379 & 0.538 & 0.999 \\
\hline & Profitability & 0.005 & 0.003 & 2.802 & 0.094 & 1.005 \\
\hline & Efficiency & -0.002 & 0.001 & 3.407 & 0.065 & 0.998 \\
\hline & Return on investment & -0.004 & 0.003 & 1.607 & 0.205 & 0.996 \\
\hline & Financial leverage & 0.001 & 0.001 & 0.665 & 0.415 & 1.001 \\
\hline & Constant & -3.729 & 0.126 & 875.424 & 0.000 & 0.024 \\
\hline \multirow{8}{*}{ Step 3} & Size & 0.006 & 0.004 & 2.265 & 0.132 & 1.006 \\
\hline & Fixed assets & 0.008 & 0.003 & 9.859 & 0.002 & 1.008 \\
\hline & Financial equilibrium & -0.012 & 0.007 & 3.009 & 0.083 & 0.989 \\
\hline & Profitability & 0.005 & 0.003 & 2.832 & 0.092 & 1.005 \\
\hline & Efficiency & -0.002 & 0.001 & 2.891 & 0.089 & 0.998 \\
\hline & Return on investment & -0.004 & 0.003 & 1.679 & 0.195 & 0.996 \\
\hline & Financial leverage & 0.001 & 0.001 & 0.722 & 0.396 & 1.001 \\
\hline & Constant & -3.745 & 0.123 & 921.259 & 0.000 & 0.024 \\
\hline \multirow{7}{*}{ Step 4} & Size & 0.006 & 0.004 & 2.347 & 0.126 & 1.006 \\
\hline & Fixed assets & 0.008 & 0.003 & 9.781 & 0.002 & 1.008 \\
\hline & Financial equilibrium & -0.012 & 0.007 & 3.298 & 0.069 & 0.988 \\
\hline & Profitability & 0.005 & 0.003 & 2.844 & 0.092 & 1.005 \\
\hline & Efficiency & -0.002 & 0.001 & 2.970 & 0.085 & 0.998 \\
\hline & Return on investment & -0.004 & 0.003 & 1.714 & 0.190 & 0.996 \\
\hline & Constant & -3.743 & 0.123 & 923.942 & 0.000 & 0.024 \\
\hline \multirow{6}{*}{ Step 5} & Size & 0.004 & 0.004 & 1.240 & 0.265 & 1.004 \\
\hline & Fixed assets & 0.008 & 0.003 & 10.106 & 0.001 & 1.008 \\
\hline & Financial equilibrium & -0.013 & 0.007 & 3.776 & 0.052 & 0.987 \\
\hline & Profitability & 0.001 & 0.001 & 1.836 & 0.175 & 1.001 \\
\hline & Efficiency & -0.002 & 0.001 & 3.333 & 0.068 & 0.998 \\
\hline & Constant & -3.725 & 0.123 & 924.159 & 0.000 & 0.024 \\
\hline \multirow{5}{*}{ Step 6} & Fixed assets & 0.008 & 0.003 & 9.780 & 0.002 & 1.008 \\
\hline & Financial equilibrium & -0.013 & 0.007 & 3.826 & 0.050 & 0.987 \\
\hline & Profitability & 0.001 & 0.001 & 1.702 & 0.192 & 1.001 \\
\hline & Efficiency & -0.002 & 0.001 & 3.140 & 0.076 & 0.998 \\
\hline & Constant & -3.678 & 0.113 & 1.055 .234 & 0.000 & 0.025 \\
\hline
\end{tabular}




\begin{tabular}{|lc|c|c|c|c|c|}
\hline & Fixed assets & 0.008 & 0.003 & 9.957 & 0.002 & 1.008 \\
Step 7 & Financial equilibrium & -0.013 & 0.007 & 3.983 & 0.046 & 0.987 \\
& Efficiency & -0.001 & 0.001 & 2.144 & 0.143 & 0.999 \\
& Constant & -3.670 & 0.113 & 1061.534 & 0.000 & 0.025 \\
\hline \multirow{2}{*}{ Step 8 } & Fixed assets & 0.008 & 0.003 & 10.346 & 0.001 & 1.008 \\
& Financial equilibrium & -0.014 & 0.007 & 4.243 & 0.039 & 0.986 \\
& Constant & -3.655 & 0.111 & 1.080 .879 & 0.000 & 0.026 \\
\hline
\end{tabular}

Table 5: Stepwise logistic regression, with the backward elimination, calculated on manufacturing firms in the year 2008 and with, as a dependent variable, the firm's default after three years.

\begin{tabular}{|c|c|c|c|c|c|c|}
\hline & B & E.S. & Wald & Sig. & \multicolumn{2}{|c|}{$\operatorname{Exp}(B)$} \\
\hline \multirow{10}{*}{ Step 1} & Size & 0.000 & 0.004 & 0.000 & 0.983 & 1.000 \\
\hline & Fixed assets & 0.002 & 0.003 & 0.709 & 0.400 & 1.002 \\
\hline & Financial debts & 0.000 & 0.001 & 0.099 & 0.753 & 1.000 \\
\hline & Financial equilibrium & -0.007 & 0.005 & 1.843 & 0.175 & 0.994 \\
\hline & Return on debts & -0.002 & 0.001 & 2.053 & 0.152 & 0.998 \\
\hline & Profitability & 0.001 & 0.003 & 0.170 & 0.680 & 1.001 \\
\hline & Efficiency & -0.002 & 0.001 & 6.662 & 0.010 & 0.998 \\
\hline & Return on investment & -0.001 & 0.003 & 0.071 & 0.790 & 0.999 \\
\hline & Financial leverage & 0.001 & 0.001 & 3.235 & 0.072 & 1.001 \\
\hline & Constant & -3.163 & 0.094 & 1.126 .090 & 0.000 & 0.042 \\
\hline \multirow{9}{*}{ Step 2} & Fixed assets & 0.002 & 0.003 & 0.718 & 0.397 & 1.002 \\
\hline & Financial debts & 0.000 & 0.001 & 0.099 & 0.753 & 1.000 \\
\hline & Financial equilibrium & -0.007 & 0.005 & 1.874 & 0.171 & 0.994 \\
\hline & Return on debts & -0.002 & 0.001 & 2.052 & 0.152 & 0.998 \\
\hline & Profitability & 0.001 & 0.003 & 0.177 & 0.674 & 1.001 \\
\hline & Efficiency & -0.002 & 0.001 & 6.657 & 0.010 & 0.998 \\
\hline & Return on investment & -0.001 & 0.003 & 0.073 & 0.787 & 0.999 \\
\hline & Financial leverage & 0.001 & 0.001 & 3.236 & 0.072 & 1.001 \\
\hline & Constant & -3.162 & 0.086 & 1.355 .535 & 0.000 & 0.042 \\
\hline \multirow{8}{*}{ Step 3} & Fixed assets & 0.002 & 0.003 & 0.738 & 0.390 & 1.002 \\
\hline & Financial debts & 0.000 & 0.001 & 0.089 & 0.766 & 1.000 \\
\hline & Financial equilibrium & -0.007 & 0.005 & 1.939 & 0.164 & 0.993 \\
\hline & Return on debts & -0.002 & 0.001 & 2.177 & 0.140 & 0.998 \\
\hline & Profitability & 0.000 & 0.001 & 0.603 & 0.438 & 1.000 \\
\hline & Efficiency & -0.002 & 0.001 & 6.704 & 0.010 & 0.998 \\
\hline & Financial leverage & 0.001 & 0.001 & 3.272 & 0.070 & 1.001 \\
\hline & Constant & -3.163 & 0.086 & 1.361 .097 & 0.000 & 0.042 \\
\hline \multirow{7}{*}{ Step 4} & Fixed assets & 0.002 & 0.003 & 0.724 & 0.395 & 1.002 \\
\hline & Financial equilibrium & -0.006 & 0.005 & 1.890 & 0.169 & 0.994 \\
\hline & Return on debts & -0.002 & 0.001 & 2.308 & 0.129 & 0.998 \\
\hline & Profitability & 0.000 & 0.001 & 0.616 & 0.433 & 1.000 \\
\hline & Efficiency & -0.002 & 0.001 & 6.660 & 0.010 & 0.998 \\
\hline & Financial leverage & 0.001 & 0.001 & 3.275 & 0.070 & 1.001 \\
\hline & Constant & -3.166 & 0.085 & 1.380 .605 & 0.000 & 0.042 \\
\hline \multirow{6}{*}{ Step 5} & Fixed assets & 0.002 & 0.003 & 0.685 & 0.408 & 1.002 \\
\hline & Financial equilibrium & -0.006 & 0.005 & 1.852 & 0.174 & 0.994 \\
\hline & Return on debts & -0.002 & 0.001 & 2.207 & 0.137 & 0.998 \\
\hline & Efficiency & -0.002 & 0.001 & 6.149 & 0.013 & 0.998 \\
\hline & Financial leverage & 0.001 & 0.001 & 3.200 & 0.074 & 1.001 \\
\hline & Constant & -3.165 & 0.085 & 1.384 .684 & 0.000 & 0.042 \\
\hline \multirow{5}{*}{ Step 6} & Financial equilibrium & -0.007 & 0.005 & 2.434 & 0.119 & 0.993 \\
\hline & Return on debts & -0.002 & 0.001 & 1.962 & 0.161 & 0.998 \\
\hline & Efficiency & -0.002 & 0.001 & 6.064 & 0.014 & 0.998 \\
\hline & Financial leverage & 0.001 & 0.001 & 3.120 & 0.077 & 1.001 \\
\hline & Constant & -3.161 & 0.085 & 1.392 .275 & 0.000 & 0.042 \\
\hline \multirow{4}{*}{ Step 7} & Financial equilibrium & -0.008 & 0.005 & 2.673 & 0.102 & 0.992 \\
\hline & Efficiency & -0.002 & 0.001 & 4.478 & 0.034 & 0.998 \\
\hline & Financial leverage & 0.001 & 0.001 & 3.208 & 0.073 & 1.001 \\
\hline & Constant & -3.207 & 0.080 & 1.613 .788 & 0.000 & 0.040 \\
\hline
\end{tabular}


Table 6: Stepwise logistic regression, with the backward elimination, calculated on service firms in the year 2008 and with, as a dependent variable, the firm's default after three years.

\begin{tabular}{|c|c|c|c|c|c|c|}
\hline & $\bar{B}$ & E.S. & Wald & Sig. & \multicolumn{2}{|c|}{$\operatorname{Exp}(B)$} \\
\hline \multirow{10}{*}{ Step 1} & Size & 0.012 & 0.003 & 17.227 & 0.000 & 1.012 \\
\hline & Fixed assets & 0.004 & 0.004 & 1.024 & 0.312 & 1.004 \\
\hline & Financial debts & 0.001 & 0.001 & 2.831 & 0.092 & 1.001 \\
\hline & Financial equilibrium & 0.006 & 0.005 & 1.089 & 0.297 & 1.006 \\
\hline & Return on debts & -0.003 & 0.002 & 3.838 & 0.050 & 0.997 \\
\hline & Profitability & 0.001 & 0.003 & 0.182 & 0.670 & 1.001 \\
\hline & Efficiency & -0.002 & 0.001 & 2.485 & 0.115 & 0.998 \\
\hline & Return on investment & 0.000 & 0.003 & 0.008 & 0.931 & 1.000 \\
\hline & Financial leverage & 0.001 & 0.001 & 2.574 & 0.109 & 1.001 \\
\hline & Constant & -3.491 & 0.164 & 451.542 & 0.000 & 0.030 \\
\hline \multirow{9}{*}{ Step 2} & Size & 0.012 & 0.003 & 18.401 & 0.000 & 1.012 \\
\hline & Fixed assets & 0.004 & 0.004 & 1.025 & 0.311 & 1.004 \\
\hline & Financial debts & 0.001 & 0.001 & 2.866 & 0.090 & 1.001 \\
\hline & Financial equilibrium & 0.006 & 0.005 & 1.115 & 0.291 & 1.006 \\
\hline & Return on debts & -0.003 & 0.002 & 3.870 & 0.049 & 0.997 \\
\hline & Profitability & 0.001 & 0.001 & 1.072 & 0.300 & 1.001 \\
\hline & Efficiency & -0.002 & 0.001 & 2.498 & 0.114 & 0.998 \\
\hline & Financial leverage & 0.001 & 0.001 & 2.580 & 0.108 & 1.001 \\
\hline & Constant & -3.490 & 0.164 & 451.405 & 0.000 & 0.030 \\
\hline \multirow{8}{*}{ Step 3} & Size & 0.011 & 0.003 & 17.588 & 0.000 & 1.011 \\
\hline & Financial debts & 0.002 & 0.001 & 3.517 & 0.061 & 1.002 \\
\hline & Financial equilibrium & 0.004 & 0.005 & 0.637 & 0.425 & 1.004 \\
\hline & Return on debts & -0.003 & 0.002 & 3.415 & 0.065 & 0.997 \\
\hline & Profitability & 0.001 & 0.001 & 0.973 & 0.324 & 1.001 \\
\hline & Efficiency & -0.002 & 0.001 & 2.336 & 0.126 & 0.998 \\
\hline & Financial leverage & 0.001 & 0.001 & 2.471 & 0.116 & 1.001 \\
\hline & Constant & -3.465 & 0.161 & 462.192 & 0.000 & 0.031 \\
\hline \multirow{7}{*}{ Step 4} & Size & 0.011 & 0.003 & 17.282 & 0.000 & 1.011 \\
\hline & Financial debts & 0.002 & 0.001 & 3.305 & 0.069 & 1.002 \\
\hline & Return on debts & -0.003 & 0.002 & 3.139 & 0.076 & 0.997 \\
\hline & Profitability & 0.001 & 0.001 & 0.956 & 0.328 & 1.001 \\
\hline & Efficiency & -0.002 & 0.001 & 2.174 & 0.140 & 0.998 \\
\hline & Financial leverage & 0.001 & 0.001 & 2.296 & 0.130 & 1.001 \\
\hline & Constant & -3.453 & 0.160 & 466.180 & 0.000 & 0.032 \\
\hline \multirow{6}{*}{ Step 5} & Size & 0.011 & 0.003 & 16.872 & 0.000 & 1.011 \\
\hline & Financial debts & 0.002 & 0.001 & 3.274 & 0.070 & 1.002 \\
\hline & Return on debts & -0.003 & 0.002 & 2.906 & 0.088 & 0.997 \\
\hline & Efficiency & -0.001 & 0.001 & 1.637 & 0.201 & 0.999 \\
\hline & Financial leverage & 0.001 & 0.001 & 2.247 & 0.134 & 1.001 \\
\hline & Constant & -3.455 & 0.159 & 469.522 & 0.000 & 0.032 \\
\hline \multirow{5}{*}{ Step 6} & Size & 0.010 & 0.003 & 15.564 & 0.000 & 1.010 \\
\hline & Financial debts & 0.002 & 0.001 & 3.573 & 0.059 & 1.002 \\
\hline & Return on debts & -0.002 & 0.002 & 2.101 & 0.147 & 0.998 \\
\hline & Financial leverage & 0.001 & 0.001 & 2.410 & 0.121 & 1.001 \\
\hline & Constant & -3.461 & 0.159 & 474.318 & 0.000 & 0.031 \\
\hline \multirow{4}{*}{ Step 7} & Size & 0.010 & 0.003 & 15.134 & 0.000 & 1.010 \\
\hline & Financial debts & 0.001 & 0.001 & 3.017 & 0.082 & 1.001 \\
\hline & Return on debts & -0.002 & 0.002 & 2.076 & 0.150 & 0.998 \\
\hline & Constant & -3.441 & 0.157 & 482.219 & 0.000 & 0.032 \\
\hline \multirow{3}{*}{ Step 8} & Size & 0.009 & 0.002 & 13.583 & 0.000 & 1.009 \\
\hline & Financial debts & 0.001 & 0.001 & 2.101 & 0.147 & 1.001 \\
\hline & Constant & -3.478 & 0.155 & 501.561 & 0.000 & 0.031 \\
\hline \multirow[t]{2}{*}{ Step 9} & Size & 0.009 & 0.002 & 13.750 & 0.000 & 1.009 \\
\hline & Constant & -3.443 & 0.151 & 521.296 & 0.000 & 0.032 \\
\hline
\end{tabular}

Once the three tables related to the results of the logistic regression have been depicted, it is fair to affirm that only the sample of the commercial firms reveals such a percentage change of fixed assets, meaning a significant variable.

About the samples of manufacturing firms (out in the fifth step) and, above all, of service firms (out in the second step), the variable has got a low statistical significance (respectively wald 0.685 and wald 1.025 ) against a stronger 
significance met in the sample moulded with commercial firms (wald 10.346). For these firms, accordingly, the index built starting from the percentage change of tangible fixed assets represents the indicator, among the currently available ones, most suitable for a description of the riskiness of the firm. Just like every sector already seen, the coefficient explicated by this ratio remains always positive: the louder the upgrade of tangible fixed assets, the higher the probability of default in a firm after three years.

The final analysis (Table 7) of this study concerns the frequencies of defaults, expressed as a percentage of the total cases of default for each subdivision, in relation to ten deciles of each of the variables used

Table 7: Cluster analysis - Distribution of cases of bankruptcy within the decile of variables.

\begin{tabular}{|c|c|c|c|c|c|c|c|c|c|}
\hline Decile & Size & $\begin{array}{c}\text { Financial } \\
\text { debts }\end{array}$ & $\begin{array}{l}\text { Financial } \\
\text { equilibrium }\end{array}$ & $\begin{array}{c}\text { Return } \\
\text { on } \\
\text { debts }\end{array}$ & Profitability & Efficiency & $\begin{array}{l}\text { Return on } \\
\text { investment }\end{array}$ & $\begin{array}{l}\text { Financial } \\
\text { leverage }\end{array}$ & $\begin{array}{l}\text { Fixed } \\
\text { assets }\end{array}$ \\
\hline \multicolumn{10}{|c|}{ Manufacturing firms } \\
\hline 1 & 16.96 & 0.00 & 13.45 & 2.34 & 11.11 & 8.77 & 11.11 & 1.75 & 7.60 \\
\hline 2 & 10.53 & 2.92 & 13.45 & 7.60 & 9.36 & 10.53 & 8.77 & 5.85 & 9.94 \\
\hline 3 & 14.62 & 4.68 & 14.04 & 9.94 & 6.43 & 6.43 & 9.94 & 6.43 & 7.60 \\
\hline 4 & 7.02 & 11.70 & 10.53 & 14.04 & 11.11 & 11.11 & 7.60 & 10.53 & 11.11 \\
\hline 5 & 7.02 & 13.45 & 5.85 & 12.28 & 8.77 & 15.79 & 8.77 & 12.87 & 12.87 \\
\hline 6 & 8.19 & 21.05 & 6.43 & 12.87 & 5.85 & 17.54 & 8.77 & 11.11 & 9.94 \\
\hline 7 & 5.85 & 19.30 & 11.11 & 12.28 & 8.19 & 7.02 & 14.62 & 15.79 & 12.28 \\
\hline 8 & 8.19 & 11.70 & 8.19 & 12.28 & 18.71 & 9.36 & 11.11 & 10.53 & 8.77 \\
\hline 9 & 7.60 & 9.94 & 9.94 & 11.11 & 9.94 & 9.36 & 7.60 & 16.96 & 9.36 \\
\hline 10 & 14.04 & 5.26 & 7.02 & 5.26 & 10.53 & 4.09 & 11.70 & 8.19 & 10.53 \\
\hline \multicolumn{10}{|c|}{ Commercial firms } \\
\hline 1 & 13.68 & 1.05 & 8.42 & 1.05 & 9.47 & 12.63 & 9.47 & 9.47 & 6.32 \\
\hline 2 & 8.42 & 1.05 & 12.63 & 1.05 & 6.32 & 8.42 & 7.37 & 4.21 & 11.58 \\
\hline 3 & 6.32 & 6.32 & 14.74 & 9.47 & 7.37 & 5.26 & 4.21 & 6.32 & 6.32 \\
\hline 4 & 9.47 & 5.26 & 12.63 & 13.68 & 8.42 & 7.37 & 10.53 & 5.26 & 4.21 \\
\hline 5 & 12.63 & 15.79 & 12.63 & 16.84 & 12.63 & 16.84 & 14.74 & 6.32 & 3.16 \\
\hline 6 & 9.47 & 12.63 & 10.53 & 18.95 & 6.32 & 16.84 & 8.42 & 16.84 & 2.11 \\
\hline 7 & 6.32 & 16.84 & 7.37 & 15.79 & 9.47 & 13.68 & 16.84 & 12.63 & 15.79 \\
\hline 8 & 9.47 & 21.05 & 10.53 & 8.42 & 18.95 & 8.42 & 13.68 & 14.74 & 17.89 \\
\hline 9 & 9.47 & 8.42 & 9.47 & 6.32 & 10.53 & 5.26 & 6.32 & 12.63 & 16.84 \\
\hline 10 & 14.74 & 11.58 & 1.05 & 8.42 & 10.53 & 5.26 & 8.42 & 11.58 & 15.79 \\
\hline \multicolumn{10}{|c|}{ Service firms } \\
\hline 1 & 14.29 & 1.79 & 12.50 & 12.50 & 8.93 & 12.50 & 8.93 & 10.71 & 7.14 \\
\hline 2 & 8.93 & 3.57 & 16.07 & 7.14 & 16.07 & 8.93 & 14.29 & 10.71 & 10.71 \\
\hline 3 & 8.93 & 8.93 & 12.50 & 12.50 & 14.29 & 16.07 & 14.29 & 5.36 & 10.71 \\
\hline 4 & 5.36 & 7.14 & 10.71 & 8.93 & 7.14 & 8.93 & 12.50 & 5.36 & 8.93 \\
\hline 5 & 8.93 & 10.71 & 5.36 & 10.71 & 5.36 & 10.71 & 7.14 & 10.71 & 10.71 \\
\hline 6 & 8.93 & 12.50 & 7.14 & 10.71 & 14.29 & 12.50 & 7.14 & 10.71 & 5.36 \\
\hline 7 & 1.79 & 17.86 & 5.36 & 8.93 & 5.36 & 10.71 & 8.93 & 3.57 & 12.50 \\
\hline 8 & 5.36 & 14.29 & 10.71 & 10.71 & 12.50 & 3.57 & 7.14 & 16.07 & 10.71 \\
\hline 9 & 14.29 & 10.1 & 3.57 & 8.93 & 7.14 & 5.36 & 7.14 & 12.50 & 8.93 \\
\hline 10 & 23.21 & 12.50 & 16.07 & 8.93 & 8.93 & 10.71 & 12.50 & 14.29 & 14.29 \\
\hline
\end{tabular}

Once the samples have been subdivided in ten deciles equally distributed considering the variation of each variable, frequencies of defaults come to the light from the inside of the clusters (Muscettola \& Pietrovito, 2012a).

To ease the table observation, we marked with blue the cells inside of which an incidence of defaults lower than $10 \%$ of the cases of group would occur, and with orange the cells which, vice versa, contain a frequency of defaults above $15 \%$.

From the analysis carried out it is clear that, apart from financial debts or the return on debt (except service firms) is hard to detect some linear trends: as the cluster representing a major percentage of investment in fixed assets rises, incidences of defaults grow. Among the few variables that highlight concentrations of frequency, eventually, we notice again in the sample of commercial firms a variation of tangible fixed assets. In these clusters, indeed, there are three blue-marked cells in a row followed by four cells in orange, proving still that the cluster analysis pictures that: the higher the importance of investments in fixed assets, the weaker the health of commercial firms.

\section{CONCLUSIONS}

The implication is that the vulnerability of firms increases when they worse their working capital management. Particularly, holding highly liquid assets is important as it significantly enhances firms' effectiveness. This is because 
assets can easily and quickly be sold off and the revenue re-invested in other relatively higher short-term assets and coupled with the fact that it also prevents court actions and its associated cost emanating from the firm's inability to pay its short-term creditors. The findings further imply that a high level of debt use, normal consequence of increased fixed assets, is unhealthy for the financial success of the firm whereas increases in sales encourage firm profitability.

Over and above the effects - direct and indirect they might be - on the profitability, which results anyhow negatively affected by the world economic crisis, this paper adds to existing literature that: firms, which made investments into machinery and equipment prior to the crisis, got much more vulnerable than firms which did not touch their own composition of assets. Actually the profitability is slightly better for firms with significative investments in tangible fixed assets; some indicators of the efficiency ratios look like more appreciable but, on the other hand, the impact on the borrowings ratios and on the burden of debts resulted detrimental. It made the leverage-effect more unsteady. The crisis advent, actually, much more easily hit even firms looking more rigid and exposed to the market.

Our results are consistent with the hypotheses of prevalent literature regarding the effects of fixed assets, and this study provides a strong evidence that the expected costs of the liquidity of assets are economically significant. Tangible fixed assets have a positive effect on debt and on burden of debt. More precisely, however, a clear distinction must be emphasized on the sector to which a firm belongs. In sectors where, quite probably, investing in machinery and equipment could not result so much instrumental to the business activity, we find out a positive and economically large relation between investments in tangible fixed assets and corporate vulnerability. Among manufacturing firms, instead, the growing of firm's weakness is partially shrunk by a positive effect in terms of better productivity. In this sub-sample, as a matter of fact, there is not the same major frequency of defaults as already watched for the sub-samples of service firms and of commercial firms.

The hypothesis is that: the factor-elasticity changes during the time, and there is a relationship between investment dynamics and solvency, especially in the commercial sector. The recent economic crisis of 2008 seems an empty hearse close to Italian industries, and trade deeply suffers that outward.

Ultimately, the main result of this study is that, in a crisis period, the fixed capital investment does not properly means a major source to develop better technologies for the industry, but even a cause of vulnerability for firms due to the greater production costs and increased inflexibility of corporate assets.

\section{REFERENCES}

[1] Alderson, M., \& Betker, B. 1995. Liquidation Costs and Capital Structure. Journal of Financial Economics 39: 4569.

[2] Kim, B. 1998. Manufacturing learning propensity in operations improvement. Human Factors and Ergonomics in Manufacturing \& Service Industries, Vol 8, 1, 79-104. http://dx.doi.org/10.1002/(SICI)1520-6564(199824)

[3] Morellec, E. 2001. Asset Liquidity, Capital Structure and Secured Debt. Journal of Financial Economics, 61, 173206.

[4] Muscettola, M., \& Gallo, M. 2008. Analisi e gestione del rischio di credito. II progetto Mayflower. FrancoAngeli Editore.

[5] Muscettola, M., \& Pietrovito, F. 2012a. Le caratteristiche delle imprese insolventi. Sinergie Rapporti di ricerca, 36.

[6] Muscettola, M., \& Pietrovito, F. 2012 b. La rilevanza delle variabili finanziarie nel rating: i risultati di un'analisi empirica sulle PMI italiane. Sinergie Rapporti di ricerca, 36.

[7] Muscettola, M., \& Naccarato, F. 2013. Probability of Default and Probability of Excellence, an Inverse Model of Rating. One More Tool to Overcome the Crisis: an Empirical Analysis. Business System Review, Vol. 2, No. 2. http://dx.doi.org/10.7350/BSR.BV06.2013.

[8] Muscettola, M, 2013. Leverage Risk. The weight of borrower capital distinguishes the solvency of firms: an empirical analysis on a sample of 4,500 Italian SMEs. International Journal of Economics and Finance; Vol. 5, No. 12; 2013. http://dx.doi.org/10.5539/ijef.v5n12p24.

[9] Muscettola, M. 2014a. Structure of assets and capital structure. What are the relations with each other? An empirical analysis of a sample of Italy. European Journal of Economics and Finance; Vol. 5, No. 12; 2013. http://dx.doi.org/10.5539/ijef.v5n12p24.

[10] Muscettola, M. 2014b. Cash conversion cycle and firm's profitability. An empirical analysis on a sample of 4,226 manufacturing SMEs of Italy. International Journal of Business and Management, Vol. 9, no.5.

[11] Myers, S., \& Rajan, R., 1998. The Paradox of Liquidity. Quarterly Journal of Economics, 113, $733-771$.

[12] Pulvino, T., C. 1998. Do Asset Fire Sales Exist? An Empirical Investigation of Commercial Aircraft Transactions. The Journal of Finance Vol. 53, no. 3: 939-978. http://dx.doi.org/10.1111/0022-1082.00040.

[13] Schlingemann, F.P., Stulz, R.M., Walkling, R.A. 2002. Divestitures and the liquidity of the market for corporate assets. Journal of Financial Economics 64, 117-144.

[14] Shleifer, A, \& Vishny, R, W. 1991. Asset Sales and Debt Capacity. NBER Working papers series. 
[15] Shleifer, A., \& Vishny, R. 1992. Liquidation Values and Debt Capacity: A Market Equilibrium Approach. Journal of Finance, 47, 1343-1366.

[16] Sibilkov, V. 2004. Asset liquidity and Capital structure. The Journal of Financial and Quantitative Analysis. Vol. 44, No. 5 (Oct., 2009), pp. 1173-1196.

[17] Williamson, O. 1988. Corporate Finance and Corporate Governance. Journal of Finance, 43, 567-591. 